\title{
Influence of bioturbation by Hediste diversicolor on mercury fluxes from estuarine sediments: A mesocosms laboratory experiment
}

\author{
P.G. Cardoso ${ }^{\mathrm{a}, *}$, A.I. Lillebø ${ }^{\mathrm{b}}$, C.B. Lopes ${ }^{\mathrm{b}}$, E. Pereira ${ }^{\mathrm{b}}$, \\ A.C. Duarte ${ }^{b}$, M.A. Pardal ${ }^{\text {a }}$ \\ ${ }^{\text {a } I M A R}$ - Institute of Marine Research, Department of Zoology, University of Coimbra, 3004-517 Coimbra, Portugal \\ ${ }^{\mathrm{b}}$ CESAM - Centre for Environmental and Marine Studies, Department of Chemistry, University of Aveiro, 3810-193 Aveiro, Portugal
}

\begin{abstract}
Mercury, with its reactive forms being the most deleterious for the trophic chains, has been identified as a major pollutant in a few confined bodies of the coastal zone. Due to feeding, burrowing, and bioirrigation activities, infauna are known to play a crucial role in the biogeochemical processes of contaminants. The main goal of the present study is to evaluate the effects of Hediste diversicolor bioturbation on mercury fluxes from estuarine sediments in a mesocosms laboratory experiment. Additionally, an attempt was made to establish a relationship between the amount of remobilised mercury to the water column and the degree of contamination of the sediments using a mercury contamination gradient.

The present experiment demonstrated that the bioturbation activity caused by the gallery-diffuser $H$. diversicolor did not influence the remobilisation of mercury (in dissolved reactive forms) from the sediment to the water column. The concentration of dissolved reactive mercury in the water column also did not reflect the degree of contamination in the sediments. The results obtained were in accordance with the sediment characteristics of the Mondego Estuary and Ria de Aveiro (Portugal), since they are very rich in organic matter content, iron/manganese total and hydrous oxides. These physicochemical characteristics of the sediments may partially justify the retention of mercury by these systems, even when they are subjected to bioturbation.

In conclusion, sediments with high organic matter content and a high concentration of iron/manganese hydrous oxides allowed for efficient retention of mercury, and the bioturbation process did not seem to affect the system. Another conclusion from this study is that the remobilisation of mercury by bioturbation to the water column is not a fast process, requiring more than $24 \mathrm{~h}$.

This study constitutes an important work in the area of the effects of bioturbation on mercury remobilisation. Considering the toxicity of mercury for the biota, it is essential to evaluate the real magnitude of mercury processes occurring in estuarine systems in order to obtain essential information on metal behaviour.
\end{abstract}

(c) 2007 Elsevier Ltd. All rights reserved.

Keywords: Bioturbation; Hediste diversicolor; Mercury remobilisation; Estuarine sediments; Mesocosms experiment

\section{Introduction}

Among the most important environments of the coastal zone are estuaries, which are subjected to numerous anthropogenic disturbances that lead to habitat modification and changes in the structure and dynamic of biotic communities (Kennish, 2002). One of the environmental

\footnotetext{
* Corresponding author. Tel.: +351239 837797; fax: +351239823603.

E-mail address: gcardoso@ci.uc.pt (P.G. Cardoso).
}

problems encountered in these aquatic systems is the contaminants that are either discharged directly into these unique environments or delivered by the rivers and streams. Most contaminants entering an estuary become associated with sediment particles and may deposit within the estuarine boundaries. However, sediments may act not only as sinks, but also as sources of contaminants in aquatic systems (Mucha et al., 2004). The contamination of estuarine and coastal waters - some of the most productive and economically important ecosystems - by metals 
and organometals derived from anthropogenic activities has long been a concern. The accumulation processes of these contaminants in aquatic organisms will determine, in part, the enhancement of their adverse effects on the biota (Pereira et al., 2006). Environmental mercury may result from natural and/or anthropogenic activities; however, the anthropogenic sources of mercury are responsible for the highest environmental impact. In aquatic systems, mercury tends to be associated with suspended particles and can be removed from the water column into the sediments (Kim et al., 2004). Mercury in sediments is mainly precipitated as sulfides, which are associated with iron/ manganese hydrous oxides or incorporated into organic matter (Canário and Vale, 2004). Organic matter has a relevant role in estuarine systems since its structural features allow for its interaction with other substances, like metals, that modify its speciation, geochemical mobility, and availability to organisms. Also, iron/manganese hydrous oxides, due to their high specific superficial area and high sorptive capacities, have a high affinity for metals influencing their distribution in aquatic systems (Pereira, 1996; Turner, 2000).

In aquatic ecosystems, benthic fauna play a key role in organic matter processing and nutrient cycling at the water-sediment interface (Gilbert et al., 1998; MermillodBlondin et al., 2004). Bioturbation was defined by Richter (1952) in François et al. (2002) as: "all manner of displacements within unconsolidate sediments and soils that are produced by the activity of organisms, and is recognized as one of the major processes that affect aquatic ecosystems functions". These infaunal species may construct tubes or burrows for protection against desiccation or predators, for bioirrigation to facilitate feeding and oxygenation of their microenvironment, or to simply move through the sediment (Gilbert et al., 1998; Duchêne and Rosenberg, 2001). Bioturbation causes the redistribution of particles and interstitial water in sediment and increases the surface/area available for sediment-water interface exchange of nutrients and contaminants, thus modifying the sorption characteristics of the sediment and altering the redox potential (Mortimer et al., 1999; François et al., 2002; Benoit et al., 2006). Therefore, bioturbation affects the physical, chemical, and biological properties of the sediment. In particular, bioturbation affects the fluxes of organic matter, nutrients, and contaminants across the sediment-water interface and within the sediment column (François et al., 2002). The depth of bioturbation in the sediment varies regarding species composition and habitats, and may change the spatial distribution of biogeochemical zones up to $20 \mathrm{~cm}$ of depth (Dauwe et al., 1998 in Duchêne and Rosenberg, 2001).

Hediste diversicolor is one of the most widely distributed marine polychaetes known for being an important bioturbator of shallow coastal sediments. This polychaete lives in a mucus-lined semi-permanent branching gallery extending 6-12 cm into the sediment and occasionally to depths greater than $20 \mathrm{~cm}$ (Mortimer et al., 1999), which produces a continuous current of water carrying oxygen and food particles into the burrow (Mermillod-Blondin et al., 2004). The main goal of the present study is to evaluate the effects of $H$. diversicolor bioturbation and bioirrigation on mercury remobilisation from estuarine sediments on a mesocosms laboratory experiment. Also, the study evaluates the influence of the degree of sediment contamination on the amount of remobilised mercury to the water column.

\section{Materials and methods}

\subsection{Study sites}

Sediments were collected in May 2006 in two different temperate estuarine systems, the Mondego Estuary $\left(40^{\circ} 08^{\prime} \mathrm{N}, 8^{\circ} 50^{\prime} \mathrm{W}\right)$ (Fig. 1A) and the Ria de Aveiro $\left(40^{\circ} 38^{\prime} \mathrm{N}, 8^{\circ} 44^{\prime} \mathrm{W}\right)$ (Fig. 1B) both located on the Atlantic coast of Portugal. The Mondego Estuary is located $60 \mathrm{~km}$ south from the Ria. Sediment from the Mondego Estuary (St. 1) was taken as a reference corresponding to a condition without mercury contamination. During the last 50 years, Ria de Aveiro has experienced a continuous mercury discharge from the chlor-alkali industry, which induced an environmental contamination gradient within the inner Laranjo Basin (e.g. Pereira et al., 1998; Coelho et al., 2005). In this basin two sampling sites were chosen. The first site is located close to the mercury source point and is characterized by strongly contaminated sediments (Laranjo Basin - St. 3). The second site (St. 2) corresponds to moderately contaminated sediments and is located at the opposite end of the basin away from the mercury source point towards Chegado Quay (referred to in the figures as Chegado) (Fig. 1B). The distance between these two sampling stations is around $800 \mathrm{~m}$. These three sediment environments represent a gradient of mercury contamination while still having similar characteristics (muddy sediments). In the three sampling areas only the superficial layer of the sediment $( \pm 10 \mathrm{~cm})$ was collected for this study.

In order to reduce the natural heterogeneity and to obtain a similar set of start up conditions, the sediments were homogenised before use and all the macrofauna was removed from the sediments. The water used in the experiment was collected in the Mondego Estuary (assumed as the reference condition) and filtered through $0.45 \mu \mathrm{m}$ pore size Millipore filters.

\subsection{Sampling of invertebrates}

$H$. diversicolor was the species chosen for this study since it is an important bioturbator that is common and abundant in shallow waters (natural densities of 200-1500 individuals $\mathrm{m}^{-2}$ ) (Cardoso et al., 2007). The organisms were collected from each of the sampling sites to avoid the toxic effects, possibly death, of being in contact with contaminated sediments from other sites. In the laboratory, all the organisms were measured (first setiger width in $\mathrm{mm}$ ) 
A

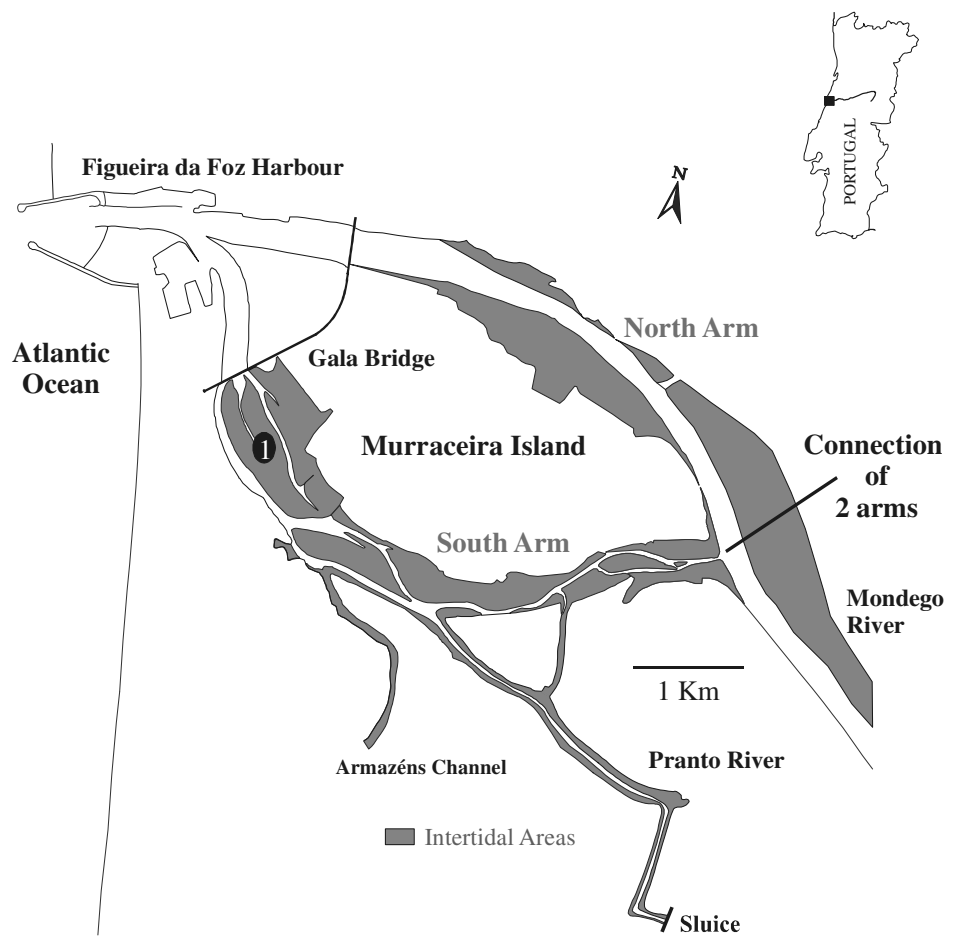

B
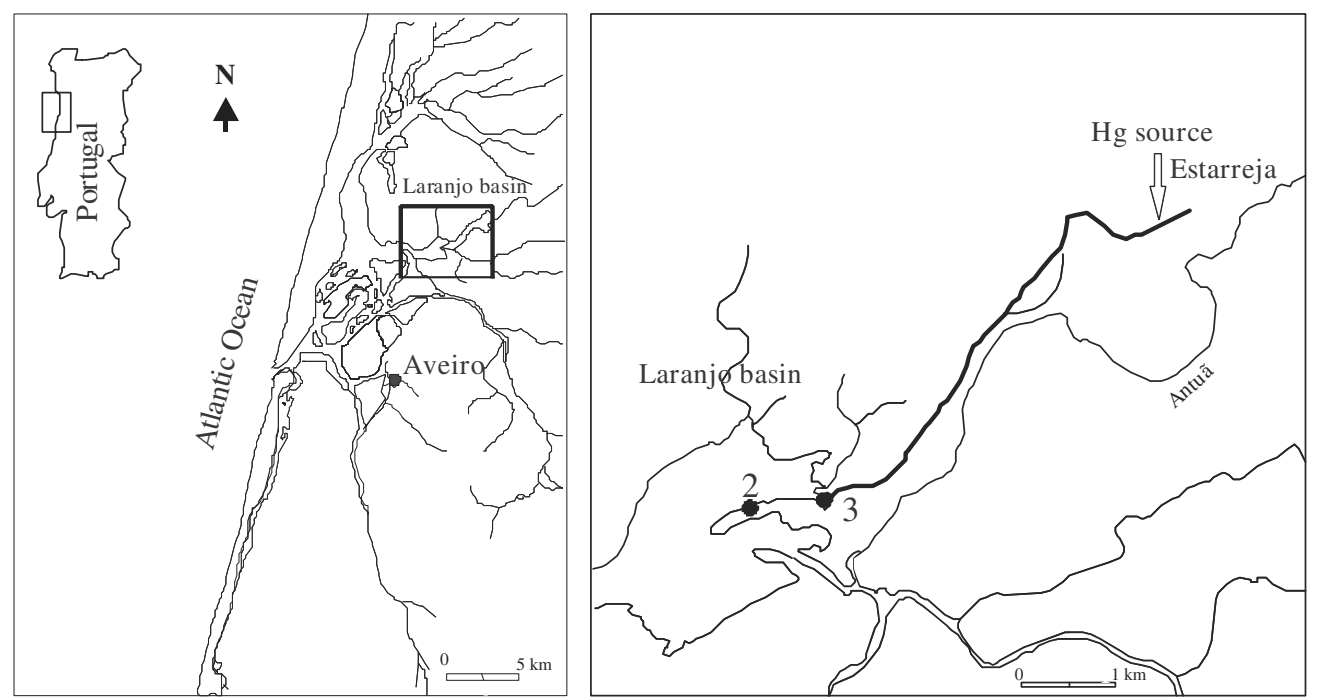

Fig. 1. Location of the sediment sampling sites: (A) St. 1 - Mondego Estuary; (B) Ria de Aveiro (St. 2 - Chegado Quay, St. 3 - Laranjo Basin)

and separated into different classes $(<1 \mathrm{~mm}, 1-2 \mathrm{~mm}$, $>2 \mathrm{~mm}$ ). All the organisms used in the experiment belonged to the class $<1 \mathrm{~mm}$, corresponding to an average burrow surface area of $1 \mathrm{~cm}^{2}$ (Mortimer et al., 1999).

\subsection{Experimental set-up}

For each of the three sampling sites three different conditions were used: Control - no fauna; Effect $\mathrm{A}-H$. diversicolor representing the mean density in the field (five organisms $\mathrm{m}^{-2}$ ) and referred to as "med"; Effect B $-H$. diversicolor representing the maximum density in the field (10 organisms $\mathrm{m}^{-2}$ ) and referred to as "max". The densities chosen were based on natural densities that occurred in the field (Cardoso et al., 2007). Three replicates were done for each condition. Therefore, in total, the experimental set-up included twenty seven sub-experiments performed in acidwashed glass containers of $3 \mathrm{~L}(\varnothing: 14 \mathrm{~cm})$.

Sediment mesocosms were established by transferring $1000 \mathrm{~g}$ (wet wt) of homogenised and free fauna sediment to each glass container. Then, $1.0 \mathrm{~L}$ of filtered $(0.45 \mu \mathrm{m})$ estuarine water from Mondego Estuary (assumed as reference) was added to each glass container. Oxic conditions were ensured by bubbling the water with atmospheric air. The glass containers were distributed at random in a dark room to avoid primary production and maintained at 
$20^{\circ} \mathrm{C}$ for a 24 -h period for stabilization before introducing the organisms. After the 24-h stabilization equilibrium period, the organisms were introduced into each glass container according to the pre-defined conditions.

\subsection{Analysis}

\subsubsection{Water samples}

Water samples $(100 \mathrm{~mL})$ were collected at the starting time $\left(t_{i}=0 \mathrm{~h}\right)$ and after $1 \mathrm{~h}\left(t_{1}\right), 12 \mathrm{~h}\left(t_{2}\right), 24 \mathrm{~h}\left(t_{3}\right)$ and $72 \mathrm{~h}\left(t_{4}\right)$. The water was filtered with $0.45 \mu \mathrm{m}$ pore size Millipore filters and acidified with concentrated $\mathrm{HNO}_{3}$ "mercury free" to a $\mathrm{pH}<2$. It was maintained in a room at $4{ }^{\circ} \mathrm{C}$. The collection of the water samples was done respecting the same sampling time for all the conditions.

Dissolved reactive mercury analysis in water samples was performed by cold vapour atomic fluorescence spectroscopy (CV-AFS), on a PSA cold vapour generator (model 10.003) that was associated with a Merlin PSA detector (model 10.023) using $\mathrm{SnCl}_{2}$ as a reducing agent. This analytical methodology is highly sensitive, allowing for the measurement of $1 \mathrm{ng} \mathrm{L}^{-1}$ of mercury. Dissolved reactive mercury was analysed directly in the acidified samples (Mucci et al., 1995).

\subsubsection{Sediment samples}

Sediment samples were collected at the starting time $\left(t_{\mathrm{i}}=0 \mathrm{~h}\right)$ and at the end of the experiment $\left(t_{\mathrm{f}}=72 \mathrm{~h}\right)$ and analysed for organic matter content, mercury, iron and manganese. The sediments were always homogenised, freeze-dried and manually sieved through a $1 \mathrm{~mm}$ mesh to remove coarser material and debris.

Organic matter content of the sediments was estimated as weight loss on ignition (\% LOI) at $450{ }^{\circ} \mathrm{C}$ over $8 \mathrm{~h}$. Fine particles (fraction less than $63 \mu \mathrm{m}$ ) were determined by wet sieving of dried sample using a $63 \mu \mathrm{m}$ mesh size sieve.

Sediment samples were analysed for total mercury by thermal decomposition atomic absorption spectrometry with gold amalgamation, using a LECO AMA-254 (Advanced Mercury Analyser).

Analytical quality control was performed by using certified reference material $(\mathrm{CRM})$. The $\mathrm{CRMs}$ used were MESS-3 (marine sediments) and PACS-2 (polluted marine sediments). Measured and certified values for total mercury in the CRMs used were in agreement, with recoveries between $82 \%$ and $93 \%$. Precision was always less than $3 \%$.

Total iron and manganese concentrations were determined after approximately $100 \mathrm{mg}$ of freeze-dried sediment was weighted into an acid-washed Teflon bomb and $1 \mathrm{~mL}$ of aqua regia and $6 \mathrm{~mL}$ of concentrated fluoridric acid were added. The Teflon reactors were sealed and placed in an oven for $1 \mathrm{~h}$ at $100{ }^{\circ} \mathrm{C}$. After cooling, the solution was quantitatively transferred into acid-cleaned $100 \mathrm{~mL}$ volumetric flasks that contained $5.6 \mathrm{~g}$ of boric acid (Rantala and Loring, 1977). The volume was made up with Milli$\mathrm{Q}$ water and agitated to promote easier dissolution of the boric acid. Then the mixture was transferred to plastic bot- tles and stored at $4{ }^{\circ} \mathrm{C}$ until further analysis. Iron and manganese were determined by Flame Atomic Absorption Spectrophotometry (FAAS; Perkin-Elmer, model AAnalyst 100). A more extended description of the analytical procedure can be found in Hoogstraten van and Nolting (1991).

A partial digestion using a hydroxylamine hydrochloride-acetic acid mixture was also used to evaluate the content of iron and manganese hydrous oxides of the sediments. This extraction was performed with $1 \mathrm{~g}$ of freeze-dried sediment, to which $20 \mathrm{~mL}$ of $0.04 \mathrm{~mol} \mathrm{~L}^{-1}$ hydroxylamine hydrochloride $\left(\mathrm{NH}_{2} \mathrm{OH}\right)$ in $25 \%$ glacial acetic acid was added. The selective extractions with a mixture of hydrochloride-acetic acid were conducted in centrifuge tubes, which were subjected to continuous agitation over 6 h (Canário et al., 2003). After extraction, solid-solution separation was made by centrifuging (B. Braun, model Sigma 4-10) at $6000 \mathrm{rpm}$ for $30 \mathrm{~min}$. The supernatant was filtered with $0.45 \mu \mathrm{m}$ pore size Millipore filters and analysed using Flame Atomic Absorption Spectrophotometry (FAAS; Perkin-Elmer, model AAnalyst 100).

\subsection{Statistical data analysis}

Two-factor ANOVA (sampling times $\times H$. diversicolor conditions) was carried out followed by a multiple comparison test (Tukey test). All data were previously checked for normality using the Kolmogorov-Smirnov test and for homogeneity of variances using the Levene's test (Zar, 1996). Data not meeting these criteria were transformed appropriately (Zar, 1996) and checked again for normality and homocedasticity.

\section{Results}

\subsection{Mercury concentrations in water column}

Dissolved reactive mercury showed the same pattern throughout time in the three sites studied. In the $t_{0}$ instance, the concentration of dissolved reactive mercury (5-10 $\mathrm{ng} \mathrm{L}^{-1}$ ) was similar in the three sites and remained constant during the first $24 \mathrm{~h}$, until the $t_{3}$ instance. In only $72 \mathrm{~h}\left(t_{4}\right)$ after the beginning of the experiment an increment of dissolved reactive mercury was recorded in the water column. Such an increment was similar in the three sites (35-40 ng L ${ }^{-1}$ ), independently of both the different densities of $H$. diversicolor and the degree of mercury contamination of the sediments (Fig. 2).

There were significant differences in dissolved reactive mercury concentrations between sampling times for the Mondego Estuary site $(P=0.000)$ but no significant differences between different densities of $H$. diversicolor $(P=0.640)$. For the Chegado Quay, there were significant differences between both sampling times $(P=0.000)$ and different densities of $H$. diversicolor $(P=0.005)$. For the Laranjo Basin site, significant differences between sampling times were observed $(P=0.000)$ (Table 1). 

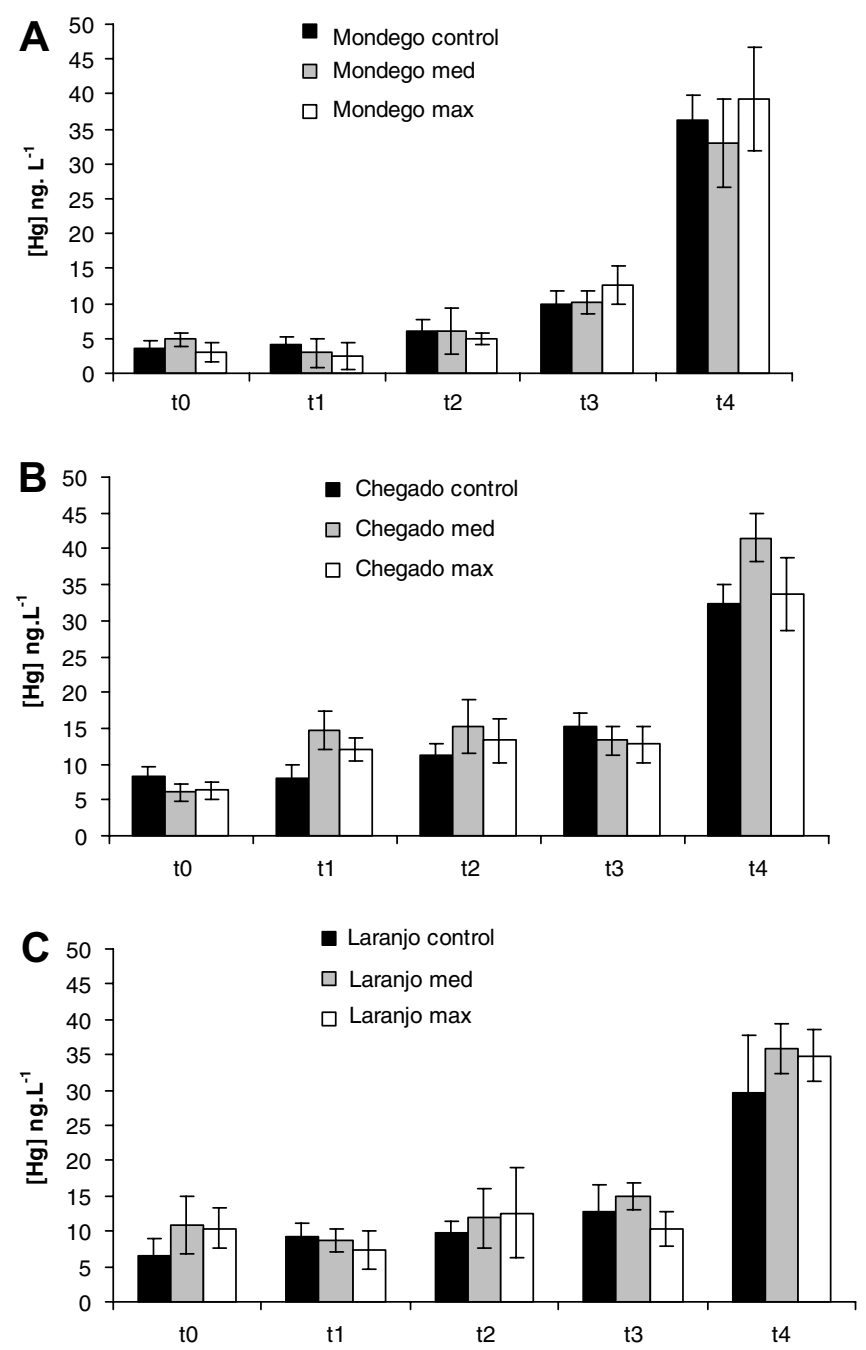

Fig. 2. Concentrations of dissolved reactive mercury $\left(\mathrm{ng} \mathrm{L}^{-1}\right)$ in the water column for different sampling times and sampling sites: (A) Mondego Estuary, (B) Chegado Quay, (C) Laranjo Basin (error bars represent standard deviation).

\subsection{Sediment characterization and mercury concentrations}

The percentage of organic matter $(\%$ LOI) of the sediments of the three sites presented similar values, with Laranjo Basin $(7 \%)$ showing slightly higher organic matter content than Chegado Quay (6\%) and Mondego Estuary $(4 \%)$ (Fig. 3). Regarding percentage of grain sizes < $63 \mu \mathrm{m}$ in the sediment, the samples showed a very similar content of $31.2 \%$ in the three sites under study.

Mercury concentrations in the sediments from the three sites clearly show the existence of a strong contamination gradient. The sediments from the Laranjo Basin contain much more mercury than those from the Chegado Quay and both sites are extremely contaminated when compared to the reference station (Mondego Estuary). Mercury concentrations in the Mondego Estuary sediments ranged between 0.08 and $0.15 \mu \mathrm{g} \mathrm{g}^{-1}$, while in Chegado Quay, the mercury concentrations attained values ranging from 9 to $10 \mu \mathrm{g} \mathrm{g}^{-1}$. Laranjo Basin presented the highest mer-
Table 1

Statistical results of the two-way analysis of variance for reactive mercury

\begin{tabular}{|c|c|c|c|c|}
\hline & \multicolumn{4}{|c|}{ Two-way ANOVA } \\
\hline & $\begin{array}{l}\text { Source of } \\
\text { variation }\end{array}$ & $\begin{array}{l}\text { Degrees of } \\
\text { freedom }\end{array}$ & $\begin{array}{l}\text { Significant } \\
\text { level }\end{array}$ & Tukey test \\
\hline \multirow[t]{3}{*}{ Mondego Estuary } & A & 4 & $* * *$ & $\begin{array}{l}t_{0}, t_{1}, t_{2}<t_{3} \\
t_{0}, t_{1}, t_{2}, t_{3}<t_{4}\end{array}$ \\
\hline & $\mathrm{B}$ & 2 & ns & \\
\hline & $\mathrm{A} \times \mathrm{B}$ & 8 & ns & \\
\hline \multirow[t]{3}{*}{ Chegado Quay } & A & 4 & *** & $\begin{array}{l}t_{0}<t_{1}, t_{2}, t_{3} \\
t_{0}, t_{1}, t_{2}, t_{3}<t_{4}\end{array}$ \\
\hline & B & 2 & $* *$ & - \\
\hline & $\mathrm{A} \times \mathrm{B}$ & 8 & ** & - \\
\hline \multirow[t]{3}{*}{ Laranjo Basin } & $\mathrm{A}$ & 4 & *** & $t_{0}, t_{1}, t_{2}, t_{3}<t_{4}$ \\
\hline & $\mathrm{B}$ & 2 & ns & \\
\hline & $\mathrm{A} \times \mathrm{B}$ & 8 & $\mathrm{~ns}$ & \\
\hline
\end{tabular}

Factor $\mathrm{A}-$ sampling times, factor $\mathrm{B}-$ density of $H$. diversicolor, $\mathrm{A} \times \mathrm{B}-$ interaction.

${ }^{*} p<0.05$.

${ }_{* * *}^{* *} p<0.01$.

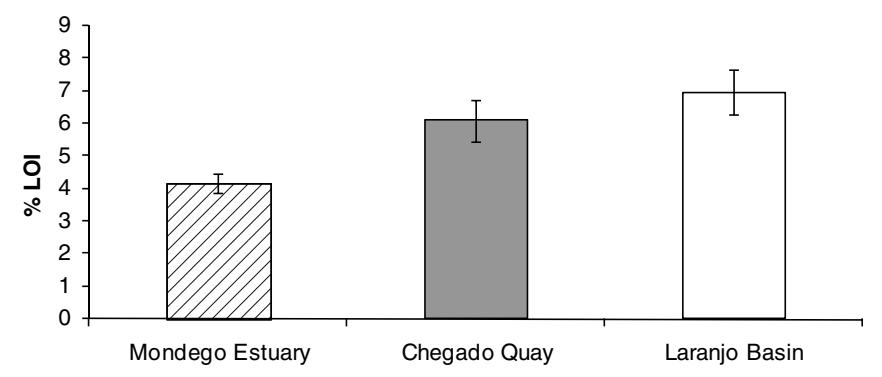

Fig. 3. Organic matter ( $\%$ LOI) in the sediment of the three sampling sites (error bars represent standard deviation).

cury concentrations ranging from 70 to $77 \mu \mathrm{g} \mathrm{g}^{-1}$ (Fig. 4). Moreover, no effect on the macrofauna at the sediment level was observed, since the concentration of mercury at the instance $t_{4}(72 \mathrm{~h})$ was similar to the one at instance $t_{0}$. In the Mondego Estuary, the concentrations of mercury in the sediments were not significantly affected by sampling times $(P=0.103)$ or different densities of $H$. diversicolor $(P=0.196)$. The same results were observed for Chegado Quay (sampling times, $P=0.258$; different densities of $H$. diversicolor, $P=0.551$ ) and Laranjo Basin sites (sampling times, $P=0.360$; different densities of $H$. diversicolor, $P=0.620$ ).

Total iron (Fig. 5A-C) and manganese concentrations (Fig. 5D-F) were relatively similar throughout the experiment. Concentrations of total iron were higher in Mondego Estuary (22738-30128 $\mathrm{g} \mathrm{g} \mathrm{g}^{-1}$ ) and Laranjo Basin (27998$\left.29156 \mu \mathrm{g} \mathrm{g}^{-1}\right)$ than at the Chegado Quay (21649$25674 \mu \mathrm{g} \mathrm{g}^{-1}$ ) site (Fig. 5A-C). Concentrations of total manganese were higher in the Mondego Estuary (162$\left.172 \mu \mathrm{g} \mathrm{g}^{-1}\right)$ than in Chegado Quay $\left(115-134 \mu \mathrm{g} \mathrm{g}^{-1}\right)$ and Laranjo Basin (122-127 $\mu \mathrm{g} \mathrm{g}^{-1}$ ) sites (Fig. 5D-F).

The concentrations of iron hydrous oxides were more abundant in Laranjo Basin followed by Chegado Quay and Mondego Estuary. In Laranjo Basin, concentrations 

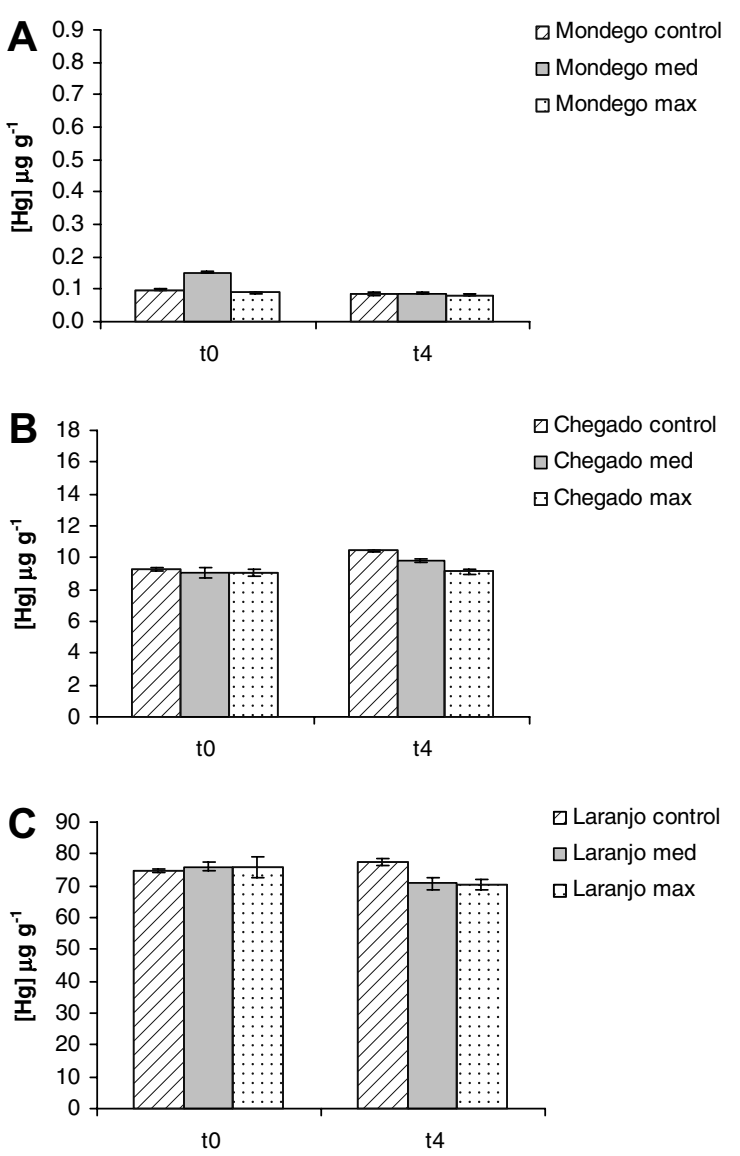

Fig. 4. Mercury concentrations $\left(\mu \mathrm{g} \mathrm{g}^{-1}\right)$ in sediments of the three sampling sites: (A) Mondego Estuary, (B) Chegado Quay, (C) Laranjo Basin (error bars represent standard deviation).

of iron hydrous oxides varied between 2516 and $2752 \mu \mathrm{g} \mathrm{g}^{-1}(8-10 \%)$. Chegado Quay and Mondego Estuary presented similar concentrations of around 1873$2075 \mu \mathrm{g} \mathrm{g}^{-1} \quad(7-9.5 \%)$ and $1940-2057 \mu \mathrm{g} \mathrm{g}^{-1} \quad(6-9 \%)$, respectively (Fig. 6A-C). Regarding the concentrations of manganese hydrous oxides, this metal presented the opposite pattern of iron, since it was more abundant in Mondego Estuary, varying between 25 and $30 \mu \mathrm{g} \mathrm{g}^{-1}(15-18 \%)$, than in the Chegado Quay, ranging between 12 and $15 \mu_{\mathrm{g} \mathrm{g}^{-1}}$ (9-12\%). Laranjo Basin presented the lowest concentrations of manganese hydrous oxides, around $10 \mathrm{\mu g} \mathrm{g}^{-1}$ (8-9\%) (Fig. 6D-F). Generally, for both metals, there were no significant differences between the sampling times $t_{0}$ and $t_{4}$. This means that $H$. diversicolor did not affect the amount of iron and manganese hydrous oxides in the sediment.

No significant concentration differences in iron hydrous oxides were observed between sampling times for any of the study sites (Mondego Estuary, $P=0.816$; Chegado Quay, $P=0.804$; Laranjo Basin, $P=0.610$ ). For manganese hydrous oxides, in both the Mondego Estuary and Laranjo Basin there were no significant differences between sampling times (Mondego Estuary, $P=0.136$; Laranjo Basin, $P=0.759$ ). However, significant differences between sampling times $(P=0.02)$ were observed for the Chegado Quay.

Table 2 summarises the characteristics of the sediments ( $\%$ of organic matter, total concentrations of iron/manganese and concentrations of iron/manganese hydrous oxides) for the studied areas compared with other worldwide coastal areas. The percentages of organic matter in the sediments of the Mondego Estuary and Ria de Aveiro were relatively higher than for the other coastal systems. The same pattern was also observed for the total concentration of iron in the sediments. The total concentration of manganese was similar in all systems, except for the Venice lagoon that was higher. On the other hand, concentrations of iron/ manganese hydrous oxides in the studied areas were of the same order of magnitude as in the other sites.

\section{Discussion}

The fate of contaminants in estuarine sediments is related to biogeochemical transformations and mobility of soluble/reactive forms of contaminants induced by chemical gradients, bioturbation and resuspension events. The activities of infaunal macro-organisms in the sediment, such as feeding, burrowing and bioirrigation, are know to play a crucial role in the exchange of organic matter, nutrients and contaminants at the sediment-water interface (Gilbert et al., 1998 and references therein). However, the present mesocosm experiment demonstrated that the bioturbation activity caused by the gallery-diffuser $H$. diversicolor did not influence the remobilisation of mercury (in dissolved reactive forms) from the sediment to the water column. The observed pattern of mercury remobilisation into the water column was the same for all the three sites and conditions (control, medium density and maximum density of $H$. diversicolor). Only at instance $t_{4}(72 \mathrm{~h}$ after the beginning of the experiment) was an increment of mercury concentration recorded in the water column. However, such an observed increment occurred in the same manner in all the three sites and the three experimental conditions. This probably means that the observed mercury concentration in the water column is due to the natural exchange of the metal with sediments rather than to the presence of the organisms, since even in the control (without organisms) the same increment in the concentration of mercury was recorded. Furthermore, the concentration of dissolved reactive mercury in the water column did not reflect the degree of contamination of the sediments. The most contaminated sediments (i.e. Laranjo Basin and Chegado Quay) should contribute to a greater efflux of dissolved reactive mercury; this result was not observed however. The observed results for mercury concentrations in the water column may be explained by taking into account the characteristics of the sediments of the Mondego Estuary and Ria de Aveiro, since these sediments are very rich in organic matter and iron/manganese hydrous oxides compared to other worldwide systems (Table 2). These physico chemical characteristics of the sediments 

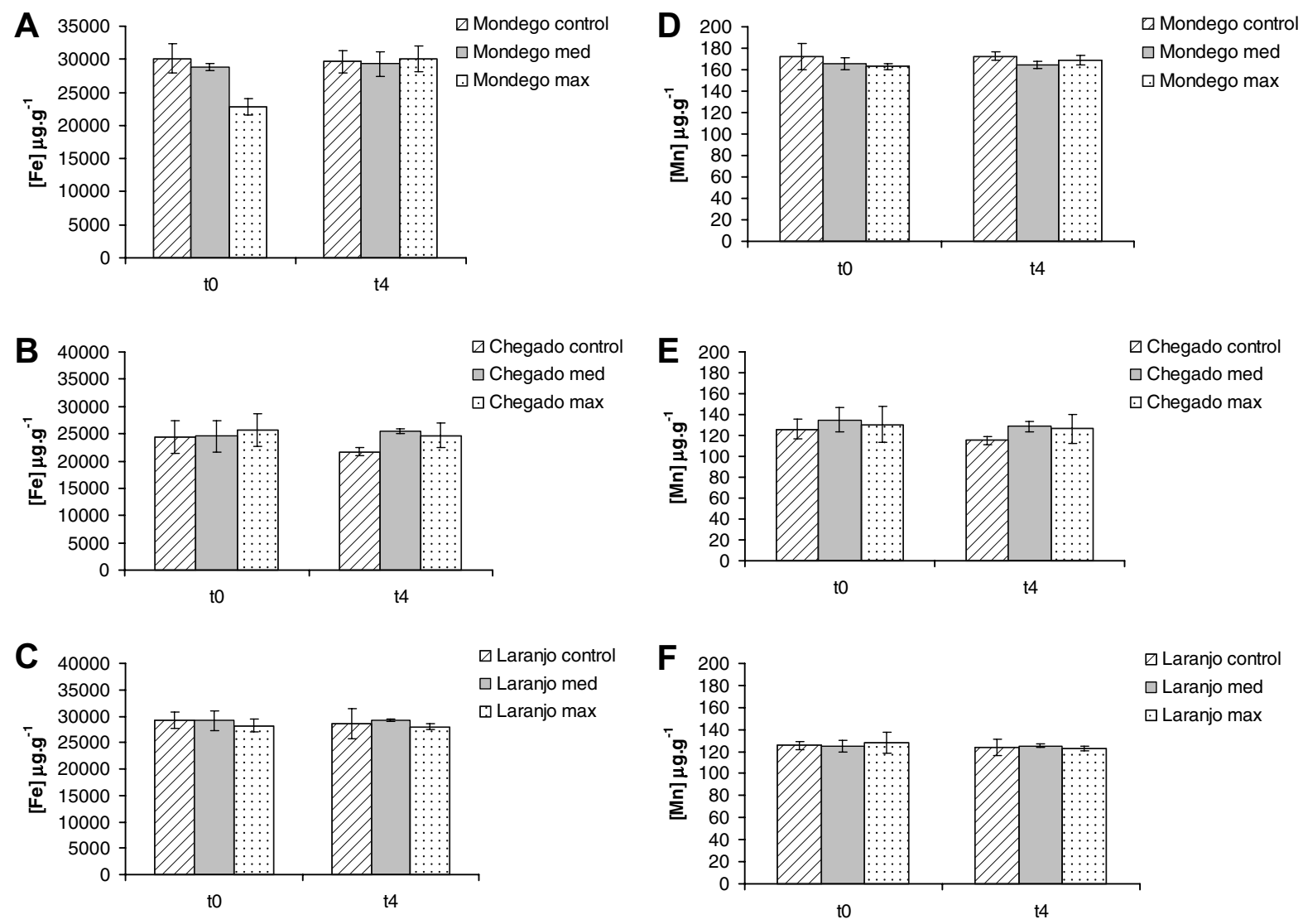

Fig. 5. Total concentration of iron and manganese $\left(\mu \mathrm{g} \mathrm{g}^{-1}\right)$ in sediments of the three sampling sites: (A) iron in Mondego Estuary, (B) iron in Chegado Quay, (C) iron in Laranjo Basin; (D) manganese in Mondego Estuary, (E) manganese in Chegado Quay, (F) manganese in Laranjo Basin (error bars represent standard deviation).

may partially justify the good retention of mercury by these systems even when they are subjected to bioturbation.

Organic matter has a relevant role in estuarine systems since its structural features allow its interaction with substances like mercury, modifying its mobility and availability to organisms. Also, the iron/manganese hydrous oxides, due to their high specific superficial area and high sorptive capacities, have a high affinity for mercury metals (Pereira, 1996; Turner, 2000). Mercury may also exist in the sediments precipitated as sulphides or associated to iron sulphides. The oxidation of these metal sulphides when exposed to oxygen, as a consequence of sediment resuspension or bioturbation, can lead to the release of associated trace metals into the water column. However, following this release, the rapid formation of iron and manganese hydrous oxides tends to sorb or coprecitate heavy metals like mercury under oxidised conditions (Caetano et al., 2003).

Despite the general recognition of the importance of bioturbation in biogeochemical processes of contaminants, there are no references about the effects of bioturbation on the remobilisation of mercury, one of the most deleterious trace metals to the biota. However, there are few works that demonstrate the important role of infauna (e.g. Hediste) on fluxes of nutrients (nitrification/denitrification) and dissolved organic carbon across the sediment-water interface (Gilbert et al., 1998; Mermillod-Blondin et al., 2004; Michaud et al., 2005, 2006). According to the literature, the gallery-diffusers (e.g. H. diversicolor) have greater effects than biodiffusers (e.g. bivalves) on the biogeochemical processes in marine sediment. Gallery-diffuser animals produce diffusion in the layer with very dense gallery systems and a bio-transport at the end of the burrows. The fauna burrows usually have significant effects on chemical fluxes and microbial activity. As $H$. diversicolor burrows deeper into the sediment, it irrigates a great volume of sediment, having a great influence on pore water chemistry, ammonium release and active bacteria (Mermillod-Blondin et al., 2004; Michaud et al., 2006). Since the ventilation of burrows by Hediste sp. is intermittent, it gives a complex temporal variability of chemical conditions, thus enhancing coupled nitrification-denitrification.

Despite the vast knowledge about the role of infauna on certain biogeochemical processes (e.g. nitrification/denitrification), there are no comparative studies concerning the effect of bioturbation on mercury remobilisation. There are just few works concerning the effects of infauna bioturbation on other heavy metals (e.g. zinc) distribution and availability (Zorn et al., 2005a,b). In accordance with our work, these studies found that the distribution and availability of zinc in soils depends on the macrofauna species 

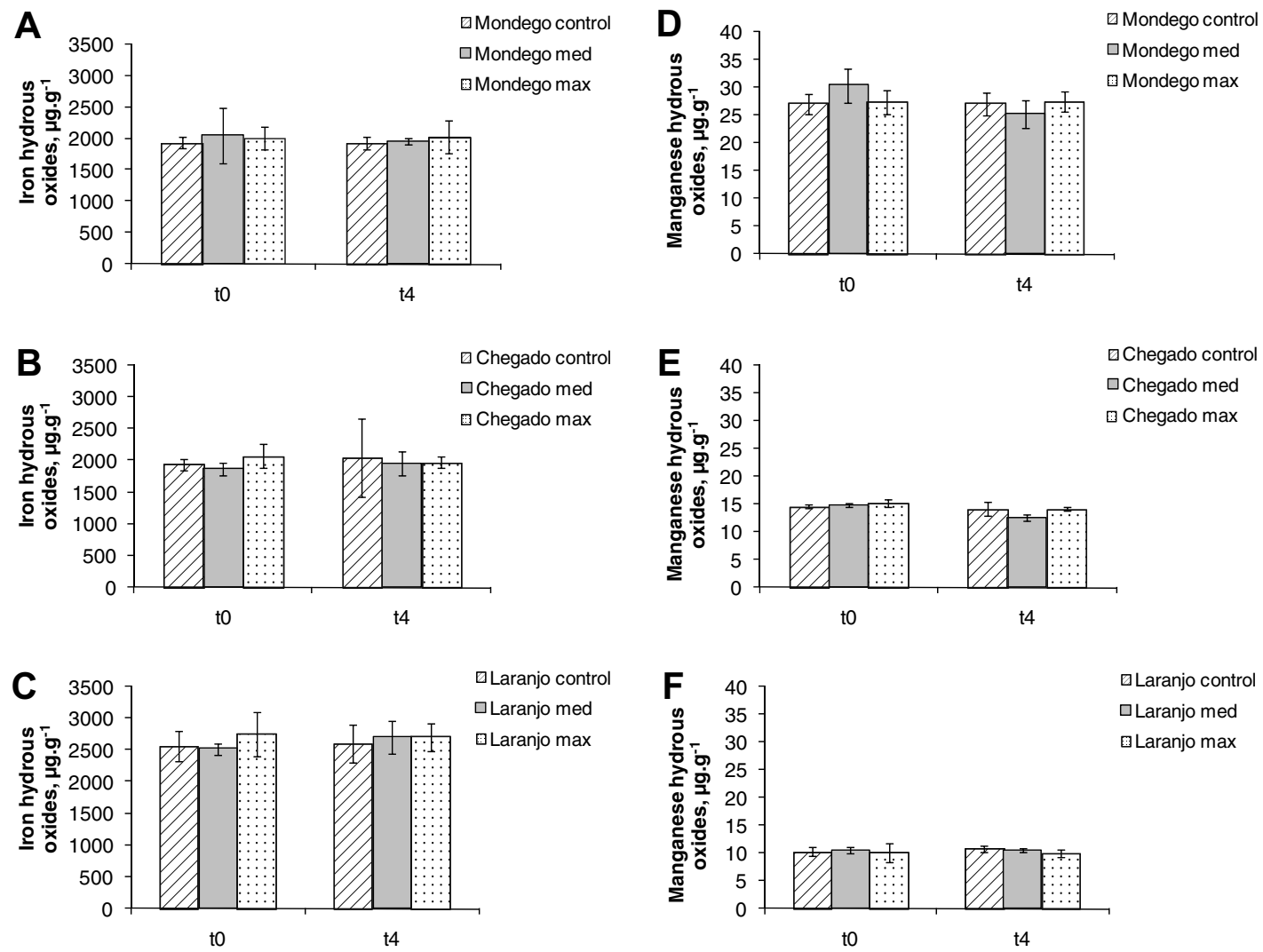

Fig. 6. Concentration of iron and manganese hydrous oxides $\left(\mu \mathrm{g} \mathrm{g}^{-1}\right)$ in sediments of the three sampling sites: (A) iron in Mondego Estuary, (B) iron in Chegado Quay, (C) iron in Laranjo Basin; (D) manganese in Mondego Estuary, (E) manganese in Chegado Quay, (F) manganese in Laranjo Basin (error bars represent standard deviation).

Table 2

Comparison of total concentration of iron and manganese in the sediments and concentrations of iron and manganese hydrous oxides in several estuaries

\begin{tabular}{|c|c|c|c|c|c|c|}
\hline \multirow[t]{2}{*}{ Study site } & \multirow[t]{2}{*}{ References } & \multirow[t]{2}{*}{$\%$ LOI } & \multicolumn{4}{|c|}{ Concentration $\left(\mu \mathrm{g} \mathrm{g}^{-1}\right)$} \\
\hline & & & Total iron & $\begin{array}{l}\text { Total } \\
\text { manganese }\end{array}$ & $\begin{array}{l}\text { Iron hydrous } \\
\text { oxide }\end{array}$ & $\begin{array}{l}\text { Manganese } \\
\text { hydrous oxide }\end{array}$ \\
\hline Chegado Quay & This study & 6 & $21649-25671$ & $115-134$ & $1873-2075$ & $12-15$ \\
\hline Laranjo Basin & This study & 7 & $27998-29156$ & $122-127$ & $2516-2752$ & 10 \\
\hline Ria Aveiro & Monterroso et al. (2007) & - & $22320-33480$ & $164-219$ & $1674-3906$ & $27.45-38.43$ \\
\hline Tagus estuary (Portugal) & Canário et al. (2003) & - & - & - & $3348-39060$ & $10.98-165$ \\
\hline Venice lagoon (Italy) & Rigollet et al. (2004) & $9-14$ & 13383 & 339 & - & - \\
\hline Thau lagoon (France) & Rigollet et al. (2004) & - & 6098 & 190 & - & - \\
\hline Dogger Bank (Central North Sea) & Langston et al. (1999) & - & $10000-20000$ & $180-500$ & - & - \\
\hline Mersey estuary, UK & Turner $(2000)$ & - & - & - & 4670 & 724 \\
\hline Clyde estuary, UK & & - & - & - & 8540 & 400 \\
\hline Dee estuary, UK & & - & - & - & 3370 & 866 \\
\hline
\end{tabular}

and is, in general, not a fast process (more than $24 \mathrm{~h})$ (Zorn et al., 2005b). According to Zorn et al. (2005a), the earthworm Lumbricus terrestris only has a slight effect on zinc availability and is able to transport polluted soil from deeper layers to the soil surface.

The present work seems to be pioneer in this area, which is very important given the relevance of mercury for the general ecosystem. Considering that mercury is a lethal element for the biota, and given its huge bioavailability in the ecosystems (Pereira et al., 1998; Canário et al., 2003; Prego and Cobelo-Garcia, 2003; Mucha et al., 2004; Ramalhosa et al., 2006), it seems imperative to do an in-depth study on the impact of macrofauna on the remobilisation of mercury into the water column. 
In conclusion, sediments with high organic matter content and high concentration of total iron/manganese and hydrous oxides allow for the efficient retention of trace metals such as mercury (high affinity for particles). Additionally, the bioturbation process may not significantly affect such a sedimentary system. On the other hand, one can also conclude from this study that the remobilisation of mercury to the water column is not a fast process and, even after $24 \mathrm{~h}, H$. diversicolor did not contribute to the effective remobilisation of mercury. However, after $72 \mathrm{~h}$ some degree of remobilisation of the metal was recorded into the water column. Based on these results, it would be very interesting in future tests to perform other experiments with a longer duration to assess the peak of efflux of mercury and also test these results for systems with other sediment characteristics.

\section{Acknowledgements}

This work was supported by FCT (Fundação para a Ciência e Tecnologia) through a Pos-Doc grant attributed to P.G. Cardoso (SFRH/BPD/22176/2005). The authors are indebted to all their colleagues, especially those from the chemistry laboratory at Aveiro University who assisted in the field and laboratory work.

\section{References}

Belzunce-Segarra, M.J., Bacon, J.R., Prego, R., Wilson, M.J., 1997. Chemical forms of heavy metals in surface sediments of the San Simon Inlet, Ria de Vigo, Galicia. Journal of Environmental Science Health 32, 1271-1292.

Benoit, J.M., Shull, D.H., Robinson, P., Ucran, L.R., 2006. Infaunal burrow densities and sediment monomethyl mercury distributions in Boston Harbor, Massachusetts. Marine Chemistry 102, 124-133.

Caetano, M., Madureira, M.J., Vale, C., 2003. Metal remobilisation during resuspension of anoxic contaminated sediment: short-term laboratory study. Water, Air and Soil Pollution 143, 23-40.

Canário, J., Vale, C., Caetano, M., Madureira, M.J., 2003. Mercury in contaminated sediments and pore waters enriched in sulphate (Tagus estuary, Portugal). Environmental Pollution 126, 425-433.

Canário, J., Vale, C., 2004. Rapid release of mercury from intertidal sediments exposed to solar radiation: a field experiment. Environmental Science Technology 38, 3901-3907.

Cardoso, P.G., Bankovic, M., Raffaelli, D., Pardal, M.A., 2007. Polychaetes as indicators of habitat recovery in a temperate estuary under eutrophication. Estuarine Coastal and Shelf Science 71, 301308.

Coelho, J.P., Pereira, M.E., Duarte, A., Pardal, M.A., 2005. Macroalgae response to a mercury contamination gradient in a temperate coastal lagoon (Ria de Aveiro, Portugal). Estuarine Coastal and Shelf Science $65,492-500$.

Duchêne, J-C., Rosenberg, R., 2001. Marine benthic faunal activity patterns on a sediment surface assessed by video numerical tracking. Marine Ecology Progress Series 223, 113-119.

François, F., Gerino, M., Stora, G., Durbec, J.-P., Poggiale, J.-C., 2002. Functional approach to sediment reworking by gallery-forming macrobenthic organisms: modeling and application with the polychaete Nereis diversicolor. Marine Ecology Progress Series 229, 127136.

Gilbert, F., Stora, G., Bonin, P., 1998. Influence of bioturbation on denitrification activity in Mediterranean coastal sediments: an in situ experimental approach. Marine Ecology Progress Series 163, 99107.

Hoogstraten van, R.J., Nolting, R.F., 1991. Trace and major elements in sediments and in porewaters from the North Western basin of the Mediterranean Sea. N1OZ Rapport 10, 1-72.

Kennish, M.J., 2002. Environmental threats and environmental future of estuaries. Environmental Conservation 29, 78-107.

Kim, E.H., Mason, R.P., Porter, E.T., Soulen, H.L., 2004. The effect of resuspension on the fate of total mercury and methylmercury in a shallow estuarine ecosystem: a mesocosm study. Marine Chemistry 86, 121-137.

Langston, W.J., Burt, G.R., Pope, N.D., 1999. Bioavailability of metals in sediments of the Dogger Bank (Central North Sea): a mesocosm study. Estuarine Coastal and Shelf Science 48, 519-540.

Mermillod-Blondin, F., Rosenberg, R., François-Carcaillet, F., Norling, K., Mauclaire, L., 2004. Influence of bioturbation by three benthic infaunal species on microbial communities and biogeochemical processes in marine sediment. Marine Ecology Progress Series 36, 271284.

Michaud, E., Desrosiers, G., Mermillod-Blondin, F., Sundby, B., Stora, G., 2005. The functional group approach to bioturbation: the effects of biodiffusers and gallery-diffusers of the Macoma balthica community on sediment oxygen uptake. Journal of Experimental Marine Biology Ecology 326, 77-88.

Michaud, E., Desrosiers, G., Mermillod-Blondin, F., Sundby, B., Stora, G., 2006. The functional group approach to bioturbation: the effects of the Macoma balthica community on fluxes of nutrients and dissolved organic carbon across the sediment-water interface. Journal of Experimental Marine Biology Ecology 337, 178-189.

Millward, G.E., Liu, Y.P., 2003. Modelling metal desorption kinetics in estuaries. The Science of the Total Environment, 613-623.

Monterroso, P., Pato, P., Pereira, M.E., Millward, G.E., Vale, C., Duarte, A., 2007. Metal-contaminated sediments in a semi-closed basin: implications for recovery. Estuarine Coastal and Shelf Science 71, $148-158$.

Mortimer, R.J.G., Davey, J.T., Krom, M.D., Watson, P.G., Frickers, P.E., Clifton, R.J., 1999. The effect of macrofauna on porewater profiles and nutrient fluxes in the intertidal zone of the Humber estuary. Estuarine Coastal and Shelf Science 48, 683-699.

Mucci, A., Lucotte, M., Montgomery, S., Plourde, Y., Pichet, P., Tra, H.V., 1995. Mercury remobilisation from flooded soils in a hydroelectric reservoir of northern Quebec, La Grande-2: results of a soil resuspension experiment. Canadian Journal of Fisheries and Aquatic Science 52, 2507-2517.

Mucha, A.P., Vasconcelos, M.T.S.D., Bordalo, A.A., 2004. Vertical distribution of the macrobenthic community and its relationships to trace metals and natural sediment characteristics in the Douro estuary, Portugal. Estuarine Coastal and Shelf Science 59, 663-673.

Pereira, M.E., 1996. Distribuiçao, reactividade e transporte do mercúrio na Ria de Aveiro. PhD thesis. University of Aveiro, $284 \mathrm{pp}$.

Pereira, M.E., Duarte, A.C., Millward, G.E., Abreu, S.N., Vale, C., 1998. Tidal export of particulate mercury from the most contaminated area of the Lagoon of Aveiro (Portugal). Water Science and Technology 37, 125-130.

Pereira, E., Abreu, S.N., Coelho, J.P., Lopes, C.B., Pardal, M.A., Vale, C., Duarte, A.C., 2006. Seasonal fluctuations of tissue mercury contents in the European shore crab Carcinus maenas from low and high contamination areas (Ria de Aveiro, Portugal). Marine Pollution Bulletin 52, 1450-1457.

Prego, R., Cobelo-Garcia, A., 2003. Twentieth century overview of heavy metals in the Galician Rias (NW Iberian Península). Environmental Pollution 121, 425-452.

Ramalhosa, E., Pato, P., Monterroso, P., Pereira, E., Vale, C., Duarte, A., 2006. Accumulation versus remobilisation of mercury in sediments of a contaminated lagoon. Marine Pollution Bulletin 52, 332-356.

Rantala, R.T.T., Loring, D.H., 1977. A Rapid Determination of 10 Elements in Marine Suspended Particulate Matter by Atomic Absorption. Atomic Absorption News 16, 51-52. 
Rigollet, V., Sfriso, A., Marcomini, A., De Casabianca, M.L., 2004. Seasonal evolution of heavy metal concentrations in the surface sediments of two Mediterranean Zostera marina L. beds at Thau lagoon (France) and Venice lagoon (Italy). Bioresource Technology 95, 159-167.

Turner, A., 2000. Trace metal contamination in sediments from UK estuaries: an experimental evaluation of the role of hydrous iron and manganese oxides. Estuarine Coastal and Shelf Science 50, 355-371.

Turner, A., Millward, G.E., Morris, A.W., 1991. Particulate metals in five major North Sea estuaries. Estuarine Coastal and Shelf Science 32, 325-346.
Zar, J., 1996. Biostatistical Analysis, third ed. Prentice-Hall International, Upper Saddle River, NJ.

Zorn, M.I., Van Gestel, C.A.M., Eijsackers, H., 2005a. The effect of Lumbricus rubellus and Lumbricus terrestris on zinc distribution and availability in artificial soil columns. Biology and Fertility of Soils 41, 212-215.

Zorn, M.I., Van Gestel, C.A.M., Eijsackers, H., 2005b. The effect of two endogeic earthworm species on zinc distribution and availability in artificial soil columns. Soil Biology and Biochemistry 37, 917-925. 